\title{
Cognitive and organizational ergonomics in the transition of the new integrated center of control of an oil refinery: human reliability and administration of changes
}

\author{
Lucy M. S. Bau ${ }^{\text {a,b* }}$, Magda S.E.S. Puquirre ${ }^{\mathrm{a}, \mathrm{b}}$, Sandro A. Buso ${ }^{\mathrm{a},}$ Érika L. Ogasawara ${ }^{\mathrm{b}}$, Carolina R. \\ Marcon Passero ${ }^{\mathrm{a}, \mathrm{b}}$, Marcos C. Bianchi ${ }^{\mathrm{a}}$ \\ ${ }^{a}$ Petrobras, Petróleo Brasileiro SA. Refinaria Presidente Getúlio Vargas. Rod. do Xisto BR 476, km 16, CEP \\ 83707.440.-Araucária- PR- Brazil. \\ ${ }^{\mathrm{b}}$ Fisiotrab Ergonomia, Saúde e Segurança no Trabalho. Av. Getúlio Vargas, 2932, Conj 406, CEP 80240.040. \\ Curitiba-PR-Brazil.
}

\begin{abstract}
The conception of a product is closely tied to its adaptation level to the users. In this view, designers are increasingly oriented to survey the needs and features of the users. This paper aims at developing a diagnosis of employees working in high-complexity activities in a petrochemical company, in light of the physical and operating changes in the Integrated Center of Control; assessing the reception sensibility to changes; assessing the cognitive pattern of the group; and making suggestions that might eliminate or minimize the difficulties in the transition process of the change, in order to reduce the adaptation period. The field of study comprised 111 production, transfer and storage operators, forming 5 groups of desktop activities. The stages of the study followed the following flow: survey of the prescribed tasks and organizational structure; Concentrated Attention test; application of the Work and Disease Risks Inventory (ITRA, Portuguese acronym); and structured psychological interview. The ITRA results pointed to a serious cognitive cost (3.83) for all five groups, this being the largest intervention focus. The items: division of task contents (3.52), social professional relationships (2.93), quality of the physical environment (2.91), physical cost (3.24), emotional cost (2.71), freedom of expression (3.77), professional fulfillment (3.41); experience and suffering (2.75), lack of recognition (2.18) and physical injuries (2.07) were considered critical. Meanwhile, social damages (1.64) and psychological injuries (1.35) are bearable. As to the Concentrated Attention test, most workers registered average level. In the individual interviews, workers showed that larger involvement in the process of physical, organizational and operational change in the desktops and on field works was required, as well as the follow up of implementations, so as to reduce the adaptation process and prevent rework (furniture, equipment, noise, form of communication with the area and training for the changes). As a result of the findings handed to the management and returned to the workers, several actions were implemented on ergonomic non-conformities found in the analysis. It is possible to prove the importance of the insertion of cognitive and organizational ergonomics in the building projects of new facilities for high-complexity activities in petrochemical plants.
\end{abstract}

Keywords: petrochemicals, management, high-complexity activities.

${ }^{*}$ Corresponding author. E-mail: lucymarabau.fisiotrab@petrobras.com.br 


\section{Introduction}

Cognitive ergonomics is concerned with mental processes, such as perception, memory, thinking and motor response, how they affect the interaction amongst human beings and other elements of a system. Organizational ergonomics is concerned with the optimization of social-technical systems, including their organizational structures, policies and processes. [1].

According to Hendrick and Kleiner [2], an ergonomic program of Nagamachi and Imada in an oil distributing company reduced industrial accidents by $54 \%$, two years after its implementation; accidents with motor vehicles by $51 \%$; accidents outside work by $84 \%$; and lost working days by $94 \%$. The result was a saving of approximately $0.5 \%$ of the global costs of the company.

Dougherty and Fragola [3] mention the risk rate due to human actions in some industries, as follows: Nuclear Industry: between 50\% and 70\%; Oil: $70 \%$; Aviation: 50\%.

\section{Materials and Methods}

The herein proposed study lies in the area of cognitive sciences because it is based on an operator's experience, memory and acquired knowledge, seeking to develop an approach on the ergonomic analysis of the operator's activity in a working situation of control over the process in the transition of a physical and operational move of the head office of the Integrated Center of Control of an oil refinery, in compliance with the Brazilian legislation, the NR 17 [4] and the technical rules of the company.

The field of the study comprised a deterministic sample of operators of the production, transfer and storage area, totaling 111 operators, who moved from their physical and operational premises to the new Head Office of the Integrated Center of Control, divided into 5 groups. The survey was carried out between August 2009 and January 2011, the transition period between the building, training and allocation of operators in the activities of the Integrated Center of Control. The inclusion criteria was operators indicated by the management to work at the desktops after the completion of the new premises of the control house, who had been working for the company for more than 2 years (the training period for all activities inherent to the process).

The stages of the study comprised two phases:

a) Before: contact with the areas for data collection; application of a census with the operators' profile; AC - Concentrated Attention - test [5]; ITRA Work and Disease Risks Inventory [6.7]; structured psychological interview; films on the desktop activities.

b)Afterwards: feedback to the management, supervisors and operators; implementation of actions resulting from the finding and confirmed as required correction demands; new application of the ITRA.

\section{Results and Discussions}

The study's target population was the labor force operating the desktops of the production (production, control, supervision and distribution of energy) and transfer and storage areas, totaling 111 operators, who participated in the first phase. The second phase comprised 41 operators of the production area; due to internal problems, the transfer and storage areas could not participate, and the utilities area had not yet made the physical transition by the end of the study.

The operators' age varied between 25 and 36 years $(31.53 \%)$ and 36 to 45 years $(36.94 \%)$, their average working period for the company being above ten years $(51.32 \%)$.

In both ITRA phases - before and afterwards little change was observed in the average, but the people migrating from "serious" to critical" or to "satisfactory" was relevant, as shown in table 1. 
Table 1

Actions resulting from the interviews of the 3 groups of production operators

\begin{tabular}{c|c|c|c|c|c|c|c|c|}
\hline \multirow{2}{*}{ Factor } & \multicolumn{4}{|c|}{ BEFORE } & \multicolumn{4}{c|}{ AFTERWARDS } \\
\cline { 2 - 10 } & Average & Serious & Critical & Satisfactory & Average & Serious & Critical & Satisfactory \\
\hline $\begin{array}{c}\text { Division of Task } \\
\text { Contents }\end{array}$ & 3.54 & 16 & 25 & 0 & 3.49 & 12 & 29 & 0 \\
\cline { 2 - 10 }$y$ & Critical & 39.02 & 60.98 & 0.00 & Critical & 29.27 & 70.73 & 0.00 \\
\hline $\begin{array}{c}\text { Quality of the } \\
\text { Physical } \\
\text { Environment }\end{array}$ & 3.06 & 6 & 32 & 3 & 2.83 & 3 & 32 & 6 \\
\cline { 2 - 10 }$y$ & Critical & 14.63 & 78.05 & 7.32 & Critical & 7.32 & 78.05 & 14.63 \\
\hline \multirow{2}{\text{CognitiveCost}}{} & 4.01 & 33 & 8 & 0 & 3.80 & 28 & 12 & 1 \\
\cline { 2 - 10 } & Serious & 80.49 & 19.51 & 0.00 & Serious & 68.29 & 29.27 & 2.44 \\
\hline
\end{tabular}

In the structured interview, demands were registered that had to be addressed in the transition.
Such demands originated several managerial actions which were carried out by specific sectors for each one of them, as shown in the table 2.

Table 2:

Actions resulting from the interviews with the 5 operating groups

\begin{tabular}{|l|l|}
\hline \multicolumn{1}{|c|}{ SUGGESTIONS } & \multicolumn{1}{c|}{ ACTIONS } \\
\hline $\begin{array}{l}\text { Lack of adequate training in passing } \\
\text { information }\end{array}$ & $\begin{array}{l}\text { Meeting with the undertaking sector (responsible for training) and } \\
\text { production to discuss improvements in the information on the } \\
\text { transitions stages to operators }\end{array}$ \\
\hline $\begin{array}{l}\text { Concern with external interferences in } \\
\text { the new CIC }\end{array}$ & $\begin{array}{l}\text { Clarification to operators on the procedures to block the entry of } \\
\text { outsiders }\end{array}$ \\
\hline Open environment to all teams & $\begin{array}{l}\text { Exhibition of the lay-out and accommodation phases of the groups by } \\
\text { working cells and communications adaptation }\end{array}$ \\
\hline $\begin{array}{l}\text { Concern over noise in the head office } \\
\text { and field operators }\end{array}$ & $\begin{array}{l}\text { Request to the phonoaudiology to analyze the radio models and } \\
\text { communication forms, with the resulting purchase of a new model, and } \\
\text { training proposal to improve the form of communications amongst } \\
\text { operators }\end{array}$ \\
\hline $\begin{array}{l}\text { Non-conformity of furniture, } \\
\text { screen/panel lay-outs }\end{array}$ & $\begin{array}{l}\text { Adjustment in the distribution of cabinets and materials; changes in the } \\
\text { position of desktop screens by frequency usage }\end{array}$ \\
\hline $\begin{array}{l}\text { Non-conformity of the access to the } \\
\text { area and excessive noise }\end{array}$ & $\begin{array}{l}\text { Access correction, equipment storage and change in the noise damper } \\
\text { type, with resulting decline in decibels }\end{array}$ \\
\hline $\begin{array}{l}\text { Non-conformity of the changing room } \\
\text { and kitchen }\end{array}$ & $\begin{array}{l}\text { Readaptation of the cabinet and seats and changes in the kitchen's } \\
\text { temperature sensor }\end{array}$ \\
\hline $\begin{array}{l}\text { More supervisor and manager follow } \\
\text { up/participation in the transition }\end{array}$ & $\begin{array}{l}\text { Meeting with managers and supervisors for the feedback on the } \\
\text { findings, with suggestions to improve the information in the transition } \\
\text { of the shift scales. }\end{array}$ \\
\hline
\end{tabular}


Films were made to observe the operating way and visual requirements vis-à-vis the 6 screens in each desktop, where the largest movement requirements had been identified, as shown in Chart 1 .

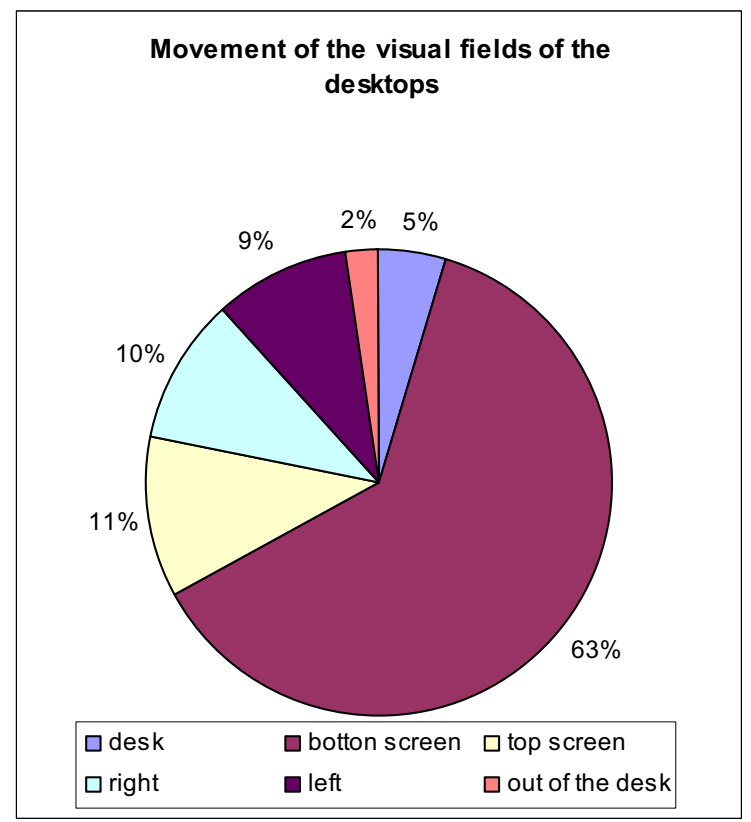

Chart 1: Movement of the visual fields of the desktops

\section{Conclusion}

During this work, the importance was evidenced of the insertion of cognitive and organizational ergonomics in the building project of new facilities for high-complexity activities of a petrochemical company, through the direct involvement of the company's operators in the project and transition process, to value their experience, the indisputable basis for the change and adaptation process, which is focused on the reliability of the processes and products.

\section{References}

[1] IEA, 2000, available at http://www.iea.cc/01 what/What $\%$ 20is\%20Ergonomics.html, accessed on: 08. ago.2011.

[2] HENDRICK, H.W. e KLEINER, B, Macroergonomia, Rio de Janeiro/RJ, Editora EVC, 2006

[3] DOUGHERTY, EM; FRAGOLA, JR, Human Reliability Analysis, 1998.

[4] LABOR AND EMPLOYMENT MINISTRY, Order nr $3.214 / 78$, of the Occupational Safety and Health Secretariat, NR 17 - Ergonomics.

[5] ALCHIERI, J.C. E CRUZ, R.M. Avaliação psicológica: conceito, métodos e instrumentos. São Paulo: Casa do Ppsicólogo, page 76, 2003.

[6] MENDES, Ana Magnólia ; FERREIRA, M. C. . Inventário sobre trabalho e riscos de adoecimento - Itra: Instrumento auxiliar de diagnóstico de indicadores críticos no trabalho. In:
Ana Magnólia Mendes. (Org.). Psicodinâmica do trabalho: teoria, método, pesquisas. 1 ed. São Paulo: Casa do Psicólogo, 2007, v. , pages 111-126

[7] MENDES, Ana Magnólia Bezerra ; FERREIRA, M. C. . Validação do Inventário sobre Trabalho e Riscos de Adoecimento (ITRA). In: Congreso Regional de la Sociedade Interamericana de Psicología, 2006, Havana Cuba. Anais do Congreso Regional de la Sociedade Interamericana de Psicología, 2006. v. 0. page 1-8. 